\title{
THE EFFECT OF GROUND GLASS WASTE ON PROPERTIES OF HARDENED CEMENT PASTE AND MORTAR
}

\author{
\#KĘSTUTIS BARKAUSKAS, DŽIGITA NAGROCKIENĖ, ARNOLDAS NORKUS \\ Vilnius Gediminas Technical University, \\ Sauletekio av. 11, Vilnius, LT-10223, Lithuania \\ "E-mail: kestutis.barkauskas@vgtu.lt
}

Submitted July 25, 2020; accepted October 2, 2020

\begin{abstract}
Keywords: Ground waste glass, Hardened cement paste, Mortar, Strength, Microstructure
The article addresses the effect of finely ground waste glass on the properties of hardened cement paste and mortar. Cement mixtures were formulated by replacing $0 \%, 5 \%, 10 \%, 15 \%, 20 \%, 25 \%$, and $30 \%$ of cement with ground waste glass. The tests revealed that hardened cement paste and mortar specimens containing $5 \%$ of ground waste glass had higher density, ultrasonic pulse velocity as well as compressive and bending strengths values. Microstructure analyses of specimens containing $5 \%$ of ground waste glass were done to determine the effect of ground waste glass on the microstructure of hardened cement paste and mortar. Cement hydration products and the contact area between the cement matrix and the ground waste glass were analysed in SEM images. The assessment of the cured mortar properties indicated that ground waste glass could be used in the manufacture of modified mortar for construction by replacing up to $5 \%$ of cement with ground waste glass.
\end{abstract}

\section{INTRODUCTION}

Glass waste accounts for approx. $5 \%$ of millions of tonnes of recyclable materials generated every year. The modification of cement-based systems with ground glass is one of the possible solutions for reusing waste glass. The use of ground waste glass as a secondary raw material reduces the amount of Portland cement necessary for the cement matrix as well as $\mathrm{CO}_{2}$ emissions from cement manufacture. Currently, the reduction of $\mathrm{CO}_{2}$ emissions from cement production is among the priorities in the European Union and worldwide. The use of recycled waste glass as a replacement for a part of cement in the production of cement systems would not only allow reducing $\mathrm{CO}_{2}$ emissions but also utilising this recyclable material without compromising the properties of cement systems.

Glass is a non-metallic and inorganic material produced by sintering certain raw materials. Glass recycling reduces energy costs and environmental pollution, also cutting down the consumption of natural raw materials. Considering that silica is the fundamental ingredient of glass, its recycling technologies can also expand the potential for waste-glass recycling and areas for the use of waste glass.

Previous research has indicated the possibilities of waste glass to be used in concrete by replacing some of the filler with ground glass [1-7].

Many researchers focused on the investigation of mortars or concrete mixtures designed with some of the aggregate replaced with waste glass. According to the studies, rheological properties of mortars or concrete mixtures improve with more than $50 \%$ of the aggregate being replaced with glass waste [8-11]. As demonstrated by various tests, ground glass, as well as other mineral additives, reduce the expansion deformations of concrete caused by the alkali-silica reaction (ASR). Researchers found that concrete modified with glass ground to the particle size of $<75$ microns had lower expansion due to alkaline corrosion [11].

Knowing that the pozzolanic activity of additives depends on the amount of silica and the specific surface area of the particles, other researchers determined the particle size affecting the pozzolanic activity of the ground glass. They argued that strength development in the specimen was slower when finely ground glass was used and that the ground glass additive could be used as a pozzolanic admixture [12-17].

Studies have shown that glass grounded to particles smaller than 75 microns have a positive effect on the mechanical properties of concrete [18-21].

Researchers from different countries conducted many investigations into the use of ground glass in the manufacture and performance improvement of concrete. The testing of specimens, which were modified with ground glass replacing a portion of cement in the mix, and which were cured for 7,14 , and 28 days showed that the amount of $20 \%$ of ground glass improved the compressive strength after 28 days of curing compared to the unmodified control specimen [22].

Other researchers investigated the portion of cement to be replaced with ground glass and determined a significant increase in the early strength of specimens, especially those modified with $15 \%$ of ground glass. Seven days of curing resulted in the improved compressive strength, which was $29 \%$ higher compared to 
the control specimens. The difference in compressive strengths of modified specimens compared to the control specimens reduced to $23 \%$ after 28 days of curing [23].

The tests conducted to analyse the effect of the replacement of a part of cement with ground glass admixture demonstrated that up to $10 \%$ of cement could be replaced with ground glass, resulting in a higher compressive strength of the specimens compared to that of the control mixture [24].

The tests in another research showed that the replacement of $40 \%$ of cement with ground glass resulted in higher compressive strength after 28 and 60 days of curing compared to the control specimens [25].

The increased amount of ground glass in the specimens reduced the compressive strength; however, the reduction became less apparent with increased curing time. The major factor influencing the compressive strength was the particle size of ground glass. Researchers investigated the properties of concrete modified using ground glass admixture and concluded that the maximum compressive strength was achieved by replacing approx. $10 \%$ of cement with ground glass. The further increase in the portion of ground glass tended to reduce the compressive strength, which became lower than that of the controls. Tests were made on the compressive strength of moulded concrete blocks, the mixture of which was modified using ground glass instead of a part of cement. The results of the study demonstrated a decrease in the strength properties after 28 days of curing [26-28].

Other researchers concluded that replacing up to $40 \%$ of cement with ground glass increased the compressive strength by up to $20 \%$; however, a further increase in the proportion resulted in the decrease of compressive strength [29].

Tests were made with fibre reinforced concrete, in which ground glass was used as a pozzolanic admixture to replace a portion of cement. The results showed a greater compressive strength compared to the control when the amount of ground glass was increased up to $30 \%$, although the maximum increase of the compressive strength was achieved by replacing $20 \%$ of cement with ground glass [30].

Researchers investigated the properties of concrete with mineral admixtures that were either affected or unaffected by alternated wetting, drying and high temperatures. Specimens that had up to $25 \%$ of cement replaced with ground glass had greater compressive strength than that of the controls; however, the most significant increase was achieved by replacing $20 \%$ of cement with ground glass in both cases, i.e., with and without alternated wetting and drying [31].

Other researchers focused on fine-grained concrete, in which a part of cement was replaced with ground glass of various fineness. The results demonstrated that $15 \%$ of cement replaced with ground glass resulted in the highest increase in the compressive strength of the specimens [32].
The impact of the size of ground glass particles on the compressive strength was determined using transparent and coloured glass crushed to particles sized from 100 to $80 \mu \mathrm{m}$, from 80 to $40 \mu \mathrm{m}$ and finer than $40 \mu \mathrm{m}$. It was demonstrated that the ground glass admixture, which was finer than $40 \mu \mathrm{m}$, resulted in the compressive strength that was by $82 \%$ higher compared to specimens with bigger ground glass particles [33].

The research focused on the effect of glass powder particles, ranging in size from $150 \mu \mathrm{m}$ to $90 \mu \mathrm{m}$ and less than $90 \mu \mathrm{m}$, on the compressive strength of concrete. Based on tests, the most optimal amount of ground glass is $20 \%$. The early compressive strength after 7 days of curing was lower than that of the controls; however, after 28 days of curing, it was higher than that of the controls. The results also demonstrated that the most effective increase in the compressive strength was using the particle size smaller than $90 \mu \mathrm{m}$ [34].

The literature review revealed that most studies focused on the use of waste glass as a replacement for aggregates or cement in concrete production, but no research results were found regarding the use of ground waste glass as a substitute for cement in the production of modified hardened cement paste and mortars. This research aimed to investigate the influence of ground waste glass on the physical and mechanical properties of hardened cement paste and mortar as well as to analyse the prospects of using ground waste glass in cement mortar.

The research has shown that it is effective to replace cement with up to $30 \%$ ground glass waste in cementbased systems, as the strength properties are only slightly reduced compared to control specimens.

\section{EXPERIMENTAL}

Tests used Portland cement CEM I $42.5 \mathrm{R}$ and ground waste glass, the physical and mechanical properties of which are given in Table 1 . Table 2 presents the chemical compositions of cement and ground waste glass. 0/4 fraction sand with a particle density of $2488 \mathrm{~kg} \cdot \mathrm{m}^{-3}$ and a bulk density of $1643 \mathrm{~kg} \cdot \mathrm{m}^{-3}$ was also used in the cement mixes tested.

Table 1. Properties of cement and ground waste glass.

\begin{tabular}{lcc}
\hline Properties & $\begin{array}{c}\text { CEM I } \\
42.5 \mathrm{R}\end{array}$ & $\begin{array}{c}\text { Ground } \\
\text { waste glass }\end{array}$ \\
\hline Specific surface $\mathrm{area}\left(\mathrm{cm}^{2} \cdot \mathrm{g}^{-1}\right)$ & 3700 & 2514 \\
Particle density $\left(\mathrm{kg} \cdot \mathrm{m}^{-3}\right)$ & 3200 & 2500 \\
Bulk density $\left(\mathrm{kg} \cdot \mathrm{m}^{-3}\right)$ & 1200 & 850 \\
Standard consistency paste (\%) & 25.4 & - \\
Initial setting time (min) & 140 & - \\
Final setting time (min) & 190 & - \\
Compres. strength after 7 days $(\mathrm{MPa})$ & 28.9 & - \\
Compres. strength after 28 days $(\mathrm{MPa})$ & 54.6 & - \\
\hline
\end{tabular}


Barkauskas K., Nagrockienè D., Norkus A.

Table 2. Chemical composition of cement and ground waste glass.

\begin{tabular}{lcrccccccrr}
\hline & \multicolumn{10}{c}{ Chemical composition (\%) } \\
\cline { 2 - 10 } & $\mathrm{SiO}_{2}$ & $\mathrm{Al}_{2} \mathrm{O}_{3}$ & $\mathrm{Fe}_{2} \mathrm{O}_{3}$ & $\mathrm{CaO}$ & $\mathrm{K}_{2} \mathrm{O}$ & $\mathrm{SO}_{3}$ & $\mathrm{Na}_{2} \mathrm{O}$ & $\mathrm{TiO}_{2}$ & $\mathrm{MgO}$ & $\mathrm{O}$ ther \\
\hline cement & 20.76 & 6.12 & 3.37 & 63.50 & 1.00 & 0.8 & 0.3 & - & - & 4.45 \\
ground waste glass & 68.15 & 12.18 & 1.30 & 3.95 & 2.80 & - & 0.75 & 0.20 & 0.90 & 9.77 \\
\hline
\end{tabular}

Compositions of specimens formed from cement stone and mortar are presented in Table 3 . The specimens were made by replacing some of the cement with ground waste glass. The water-to-cement $(\mathrm{W} / \mathrm{C})$ ratio was kept for all specimens and amounted to 0.46 .

The cement paste and mortar were mixed mechanically using a laboratory mortar mixer. The mixing time was 240 seconds. The mixed paste and mortar were poured into standard $40 \times 40 \times 160 \mathrm{~mm}$ moulds and cured for $24 \mathrm{~h}$. After one day, the moulds were disassembled and the specimens were further cured in water at $20 \pm$ $1.0{ }^{\circ} \mathrm{C}$ for 27 days.

Table 3. Mixing proportion of hardened cement paste and mortar specimens modified with glass powder.

\begin{tabular}{|c|c|c|c|c|c|c|c|}
\hline $\begin{array}{l}\text { Amount of ground } \\
\text { waste glass }(\%)\end{array}$ & 0 & 5 & 10 & 15 & 20 & 25 & 30 \\
\hline \multicolumn{8}{|c|}{ Hardened cement paste composition $(\%)$} \\
\hline Cement & 69 & 64 & 59 & 54 & 49 & 44 & 39 \\
\hline Water & 31 & 31 & 31 & 31 & 31 & 31 & 31 \\
\hline \multicolumn{8}{|c|}{ Mortar composition (\%) } \\
\hline Cement & 26.9 & 25.6 & 24.3 & 22.9 & 21.6 & 20.2 & 18.9 \\
\hline Sand & 60.6 & 60.6 & 60.6 & 60.6 & 60.6 & 60.6 & 60.6 \\
\hline Ground glass & 0.1 & 1.4 & 2.7 & 4.1 & 5.4 & 6.8 & 8.1 \\
\hline Water & 12.4 & 12.4 & 12.4 & 12.4 & 12.4 & 12.4 & 12.4 \\
\hline
\end{tabular}

Determination of pozzolanic activity. For the research was used $0.1 \mathrm{~N} \mathrm{HCl}$ soak and $0.1 \%$ phenolphthalein dissolved in $50 \%$ alcohol were used to determine the pozzolanic activity in the specimens tested. Investigation process: $1 \mathrm{~g}$ of the test sample is poured to an Erlenmeyer flask and heated to $90{ }^{\circ} \mathrm{C}, 250 \mathrm{ml}$ of distilled water is added and $2 \mathrm{~g}$ of $\mathrm{CaO}$ A magnetic element is placed in the flask, and the soak is stirred with a magnetic stirrer. The soak at $85 \pm 5^{\circ} \mathrm{C}$ is stirred for 16 hours, afterwards it is cooled to room temperature. $250 \mathrm{ml}$ of freshly prepared sucrose soak (60 g of sucrose dissolved in $250 \mathrm{ml}$ of distilled water) is added to the cooled soak and stirred for a 15 minutes. Then $200 \mathrm{ml}$ of the soak is filtered and $25 \mathrm{ml}$ of the soak is taken with a calibrated pipette. The same process is performed with a soak without a test sample. $25 \mathrm{ml}$ of the soak taken as indicated above is titrated with $0,1 \mathrm{~N} \mathrm{HCl}$ using a $0.1 \%$ phenolphthalein indicator. The amount of bound $\mathrm{Ca}(\mathrm{OH})_{2}$ is calculated in $\mathrm{mg}$ from the following equation: Content of bound $\mathrm{Ca}(\mathrm{OH})_{2} \mathrm{mg} /$ pozzolan $\mathrm{g}=$ $=2 \mathrm{~V} 1-\mathrm{V} 2 \mathrm{~V} 17456 \cdot 1000$; Here: V1 is the volume of titrated $0,1 \mathrm{~N} \mathrm{HCl}$ for the control sample; $\mathrm{V} 2$ is the volume of titrated $0,1 \mathrm{~N} \mathrm{HCl}$ for the sample with the test substance. The research has shown that the pozzolanic activity of ground glass was $344 \mathrm{mg} \mathrm{g}^{-1}$ in terms of the amount of bound $\mathrm{Ca}(\mathrm{OH})_{2}$.

The fundamental physical and mechanical properties of hardened cement paste and mortar were determined basing on the applicable standards. The density of the specimens was established following the requirements of standard EN 772-13, the compressive strength according to EN 196-1, and the ultrasonic pulse velocity according to LST EN 12504-4: 2004.

A SmartLab (Rigaku) diffractometer was used to determine the phase composition of hardened cement paste specimens. X-ray diffraction patterns were recorded at the angular range $5-75^{\circ}(2 \theta)$, detector step $0.02^{\circ}$, and the detector movement speed $1^{\circ}$ per minute. The analysis was done using the Database of Crystal Structures PDF- 4+ (2016).

The microstructure of hardened cement paste, mortar and ground waste glass was established by means of SEM microscopy. Tests were made using a scanning electron microscopy (SEM) device SEM JEOL 7600.

\section{RESULTS AND DISCUSSION}

Granulometry used to estimate the particle size distribution of ground waste glass showed that $15.1 \mu \mathrm{m}$ was the most common particle size of ground waste glass used in tests. $90 \%$ of the particles were smaller than $29 \mu \mathrm{m}, 50 \%$ were smaller than $13.85 \mu \mathrm{m}$ and $10 \%$ were smaller than $2.69 \mu \mathrm{m}$. Figure 1 presents the particle distribution of ground waste glass.

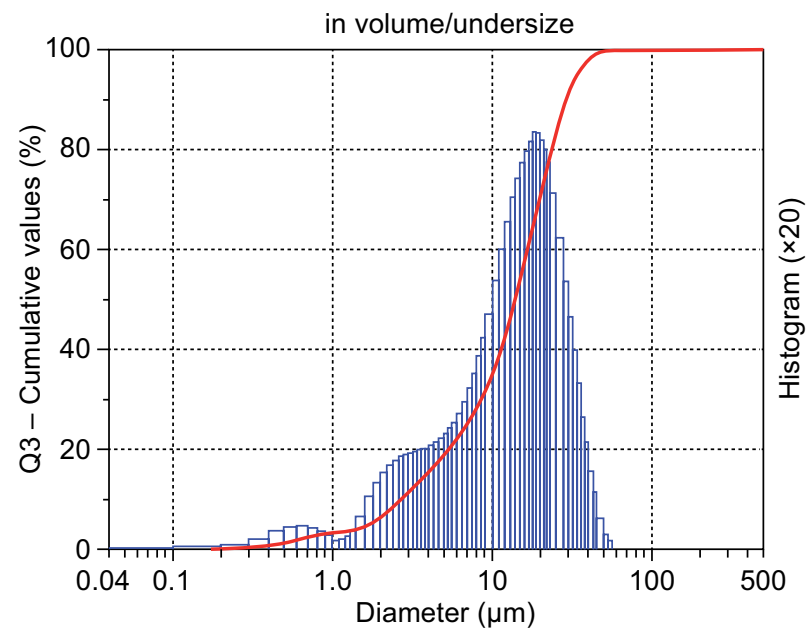

Figure 1. Granulometry of ground waste glass. 


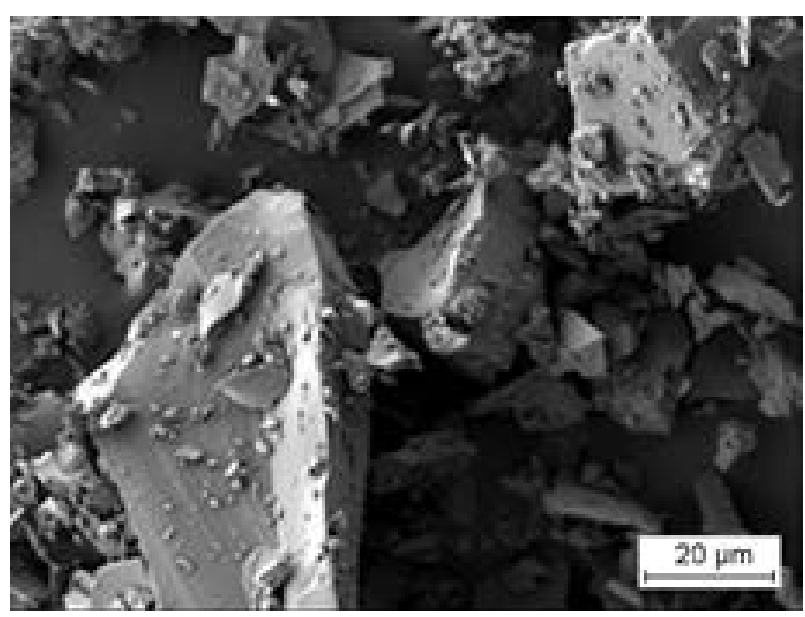

a)

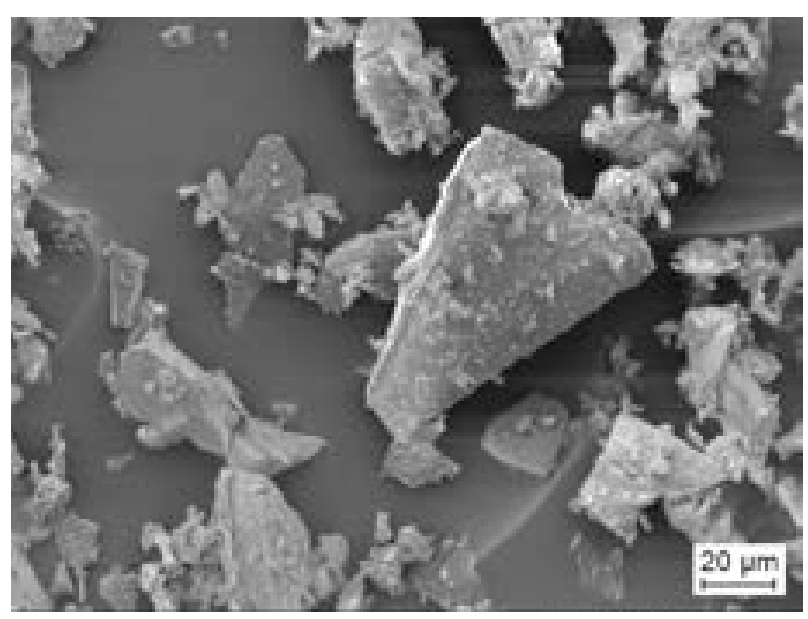

b)

Figure 2. Microstructure of glass powder: a) magnification $\times 500$, b) magnification $\times 950$.

Figure 2 presents the results of the SEM test per-formed on the ground waste glass. According to Figure 2a, particles of ground waste glass had an irregular shape and an average size of approx. $15 \mu \mathrm{m}$. The image was magnified 950 times (Figure $2 b$ ) to reveal irregular and angular shales of particles in sizes of up to $0.56 \mu \mathrm{m}$.

Densities of hardened cement paste were determined after 7, 28 and 56 days of curing (Figure 3). The highest value of density amounting to $1902 \mathrm{~kg} \cdot \mathrm{m}^{-3}$ was obtained after 7 days of curing the hardened cement paste, in which $5 \%$ of cement was replaced with ground waste glass. After 28 days of curing, the maximum density value of the hardened cement paste, in which $5 \%$ of cement was replaced with ground waste glass, was $1910 \mathrm{~kg} \cdot \mathrm{m}^{-3}$. Compared to the density of control specimens amounting to $1870 \mathrm{~kg} \cdot \mathrm{m}^{-3}$, the difference equals to $40 \mathrm{~kg} \mathrm{~m}^{-3}$ $(2.62 \%)$. The increased amount of ground waste glass up to $30 \%$ resulted in the smallest density value of $1829 \mathrm{~kg} \cdot \mathrm{m}^{-3}$, which was $31 \mathrm{~kg} \cdot \mathrm{m}^{-3}(2.68 \%)$ less than that of the control specimens. 56 days of curing showed a persistent trend similarity with maximum density values of $1922 \mathrm{~kg} \cdot \mathrm{m}^{-3}$ achieved by the hardened cement paste,

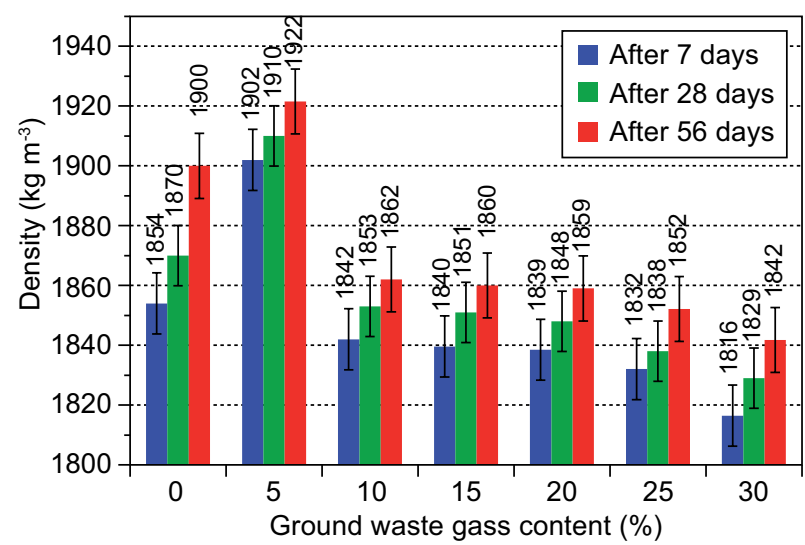

Figure 3. Relationship between the density and the amount of ground waste glass in hardened cement paste. in which $5 \%$ of cement was replaced with ground waste glass. This result was $62 \mathrm{~kg} \cdot \mathrm{m}^{3}$ (3.23\%) greater compared to the control specimen with $1891 \mathrm{~kg} \cdot \mathrm{m}^{-3}$. The increased amount of ground waste glass up to $30 \%$ resulted in the lowest density value of $1842 \mathrm{~kg} \cdot \mathrm{m}^{-3}$. This result was $49 \mathrm{~kg} \cdot \mathrm{m}^{-3}(2.59 \%)$ less than that of the control specimens.

The tests determined the effect of the amount of ground waste glass on the ultrasonic pulse velocity in hardened cement paste specimens (Figure 4). In the hardened cement paste, in which $5 \%$ of cement was replaced with ground waste glass, the increase in the ultrasonic pulse velocity was determined after 7, 28 and 56 days of curing, amounting to $3445 \mathrm{~m} \cdot \mathrm{s}^{-1}, 3554 \mathrm{~m} \cdot \mathrm{s}^{-1}$, and $3747 \mathrm{~m} \cdot \mathrm{s}^{-1}$, respectively. Compared to the values of the control specimens, these results represent a difference of $1.27 \%, 2.87 \%$ and $2.5 \%$, respectively. However, a further increase in the amount of ground waste glass resulted in decreased values of the ultrasonic pulse velocity. After 7, 28 and 56 days of curing, the control specimens not modified with ground waste glass had

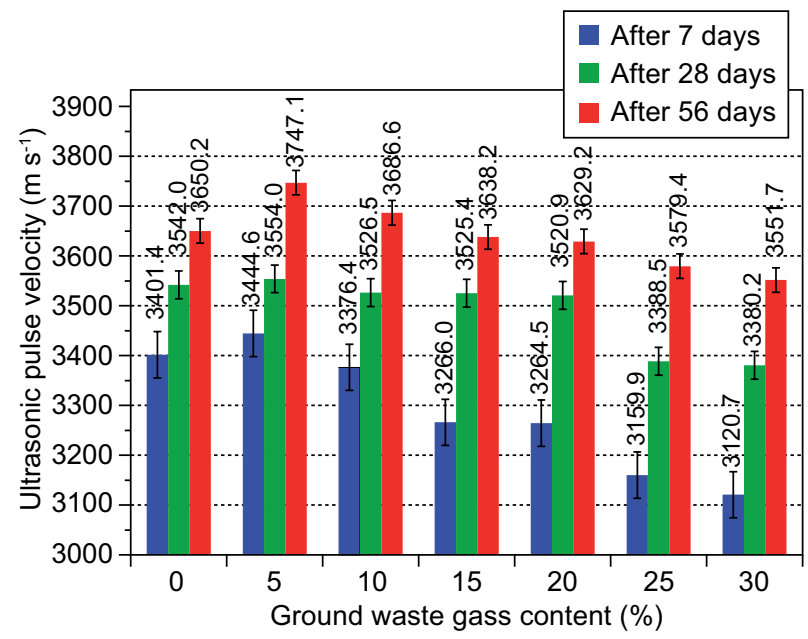

Figure 4. Relationship between the ultrasonic pulse velocity and the amount of ground waste glass in hardened cement paste. 
the values of the ultrasonic pulse velocity amounting to $3401 \mathrm{~m} \cdot \mathrm{s}^{-1}, 3542 \mathrm{~m} \cdot \mathrm{s}^{-1}$ and $3650 \mathrm{~m} \cdot \mathrm{s}^{-1}$, respectively. The ultrasonic pulse velocity test results contribute to and confirm the results of density measurement.

Figure 5 presents the results of the compressive strength tests made with hardened cement paste. The highest compressive strength of 38.0 MPa was obtained after 7 days curing in hardened cement paste specimens, in which $5 \%$ of cement was replaced with ground waste glass. After 28 days of curing the hardened cement paste modified with $5 \%$ of ground waste glass had the highest compressive strength of $39.9 \mathrm{MPa}$. The increased amount of ground waste glass up to $30 \%$ resulted in the lowest compressive strength value of $30.2 \mathrm{MPa}$. 56 days of curing showed a persistent trend similarity with the highest compressive strength of $51.7 \mathrm{MPa}$ achieved by the hardened cement paste, in which $5 \%$ of cement was replaced with ground waste glass. The increased amount of ground waste glass up to $30 \%$ resulted in the lowest compressive strength value of $40.9 \mathrm{MPa}$.

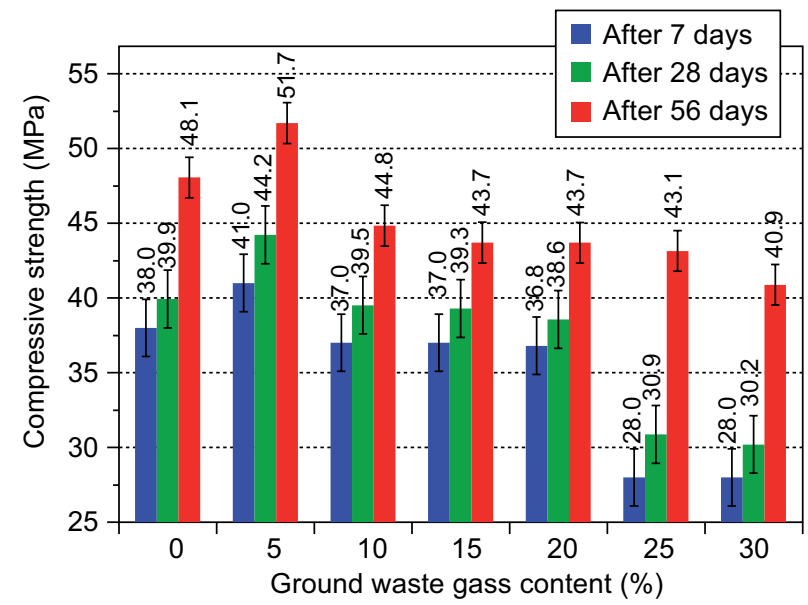

Figure 5. Relationship between the compressive strength and the amount of ground waste glass in hardened cement paste.

Based on the analysis of density, ultrasonic pulse velocity and compressive strength test results leads to the conclusion that up to $5 \%$ of cement can be replaced with ground glass in hardened cement paste without any deterioration of mechanical properties.

Figure 6 shows the relationship between the bending strength and the amount of ground waste glass in hardened cement paste specimens cured for 7, 28 and 56 days. After seven days of curing, the bending strength values continued to rise steadily with the increase in the amount of ground waste glass up to the limit of $5 \%$. The highest value of the bending strength, which was $0.57 \mathrm{MPa}$ higher than that of the control specimen and represented a $10 \%$ variation, was determined as a result of modifying hardened cement paste with $5 \%$ of the ground waste glass. However, a further increase in the amount of ground waste glass to $10 \%$ of cement content

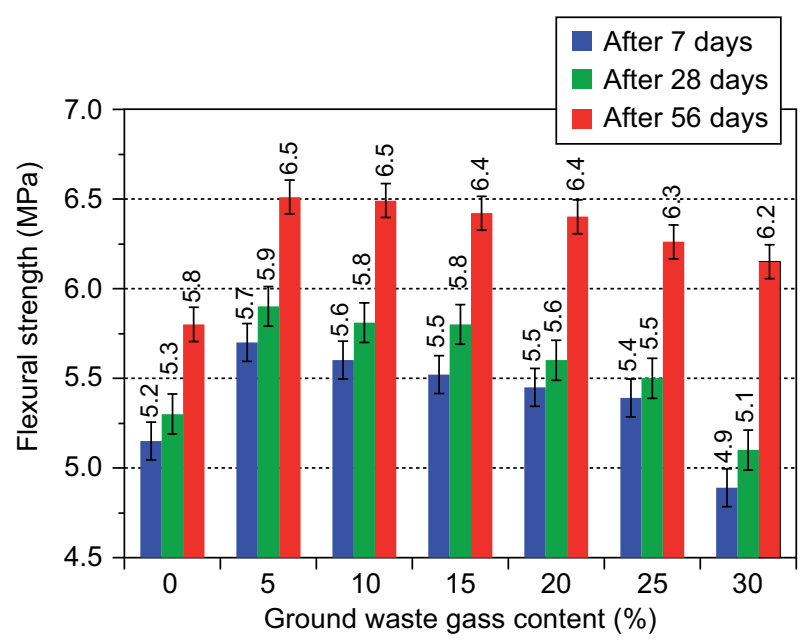

Figure 6. Relationship between the bending strength and the amount of ground waste glass in hardened cement paste.

resulted in decreasing values of the bending strength, which amounted to $5.6 \mathrm{MPa}$.

In the case of specimens cured for 28 days, the bending strength values grew with the increase of ground waste glass content up to $5 \%$. The bending strength of the control specimen without ground waste glass was $5.3 \mathrm{MPa}$. The replacement of $5 \%$ of cement with ground waste glass resulted in the highest bending strength of $5.9 \mathrm{MPa}$, which was $0.6 \mathrm{MPa}$ or $8.1 \%$ higher compared to the control specimen. A further increase in the amount of ground waste glass to $10 \%$ of cement content resulted in decreasing values of the bending strength, which amounted to $5.8 \mathrm{MPa}$.

56 days of curing resulted with the growing values of the bending strength with the increase in the amount of ground waste glass up to $5 \%$. The replacement of $5 \%$ of cement with ground waste glass resulted in the highest bending strength of $6.51 \mathrm{MPa}$, which was $0.71 \mathrm{MPa}$ or $10.9 \%$ higher compared to the control specimen. A further increase in the amount of ground waste glass to $10 \%$ of cement content resulted in decreasing values of the bending strength, which amounted to $6.35 \mathrm{MPa}$.

Figure 7 presents an X-ray analysis of specimens without ground waste glass (control specimen) (Figure $7 \mathrm{a}$ ) and with $5 \%$ and $30 \%$ of cement replaced with ground waste glass. It was found that hardened cement paste without ground waste glass consisted of $62.75 \%$ of portlandite, $33 \%$ of calcium carbonate, and other minerals. Hardened cement paste specimens that contained $5 \%$ of ground waste glass (Figure $7 \mathrm{~b}$ ) were predominantly made of portlandite, which amounted to $58.46 \%$, and which was $4.29 \%$ less compared to control specimens. The amount of calcium carbonate was $36 \%$, which was $3 \%$ more compared to control specimens. Also, some periclase (5.4\%) was found in the specimens, none of which was present in control specimens, as well as other minerals making up the remaining part. Figure 7c presents an X-ray analysis of specimens that had 
$30 \%$ of cement replaced with ground waste glass. They were predominantly made of portlandite, amounting to $59 \%$, which was $3.75 \%$ less compared to control specimens. Also, calcite amounted to $22 \%$, which was
$11 \%$ less compared to control specimens, and hatrurite amounted to $10 \%$, none of which was present in control specimens, while diopside made up $5.8 \%$ and was only found in specimen s where $30 \%$ of cement was replaced

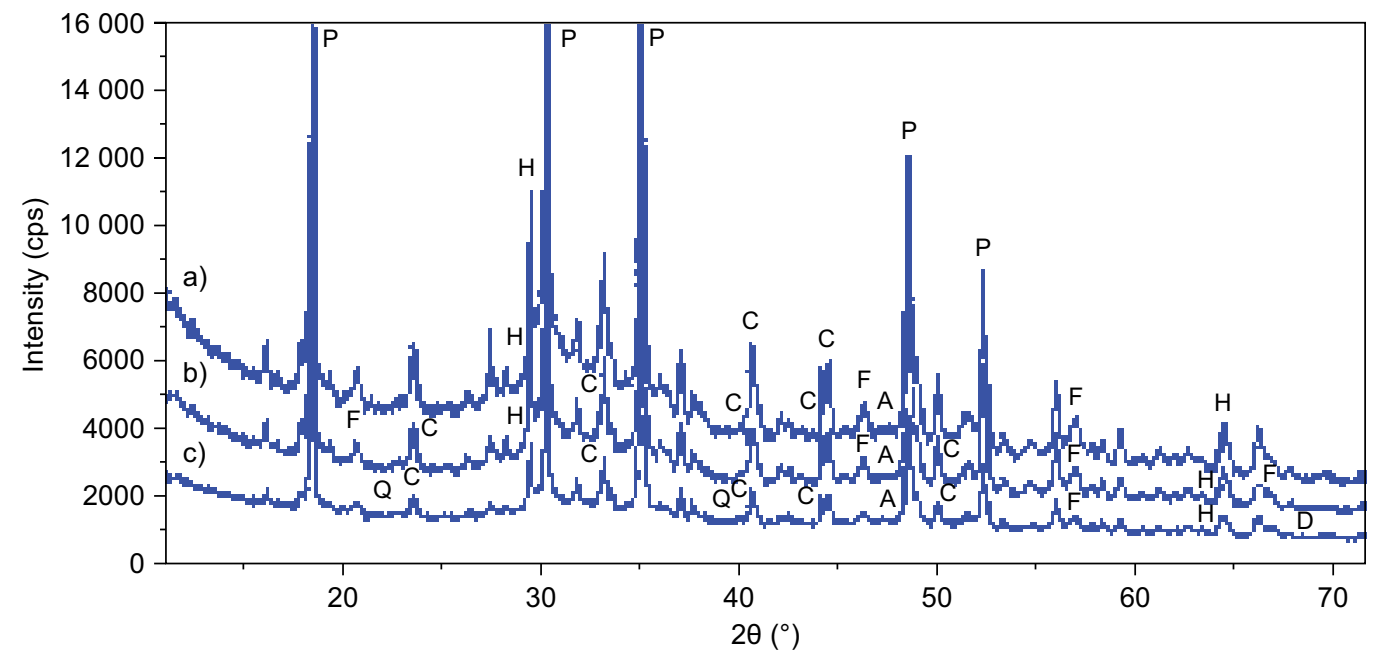

Figure 7. X-ray image of hardened cement paste: a) without ground waste glass; b) with $5 \%$ of ground waste glass; c) with $30 \%$ of ground waste glass ( $\mathrm{P}$ - Portlandite; $\mathrm{C}$ - Calcium Carbonate; $\mathrm{A}$ - Calcium Aluminium Silicate Hydroxide; L - Larnite; D - Diopside; $\mathrm{H}$ - Hatrurite; Q - Quartz.
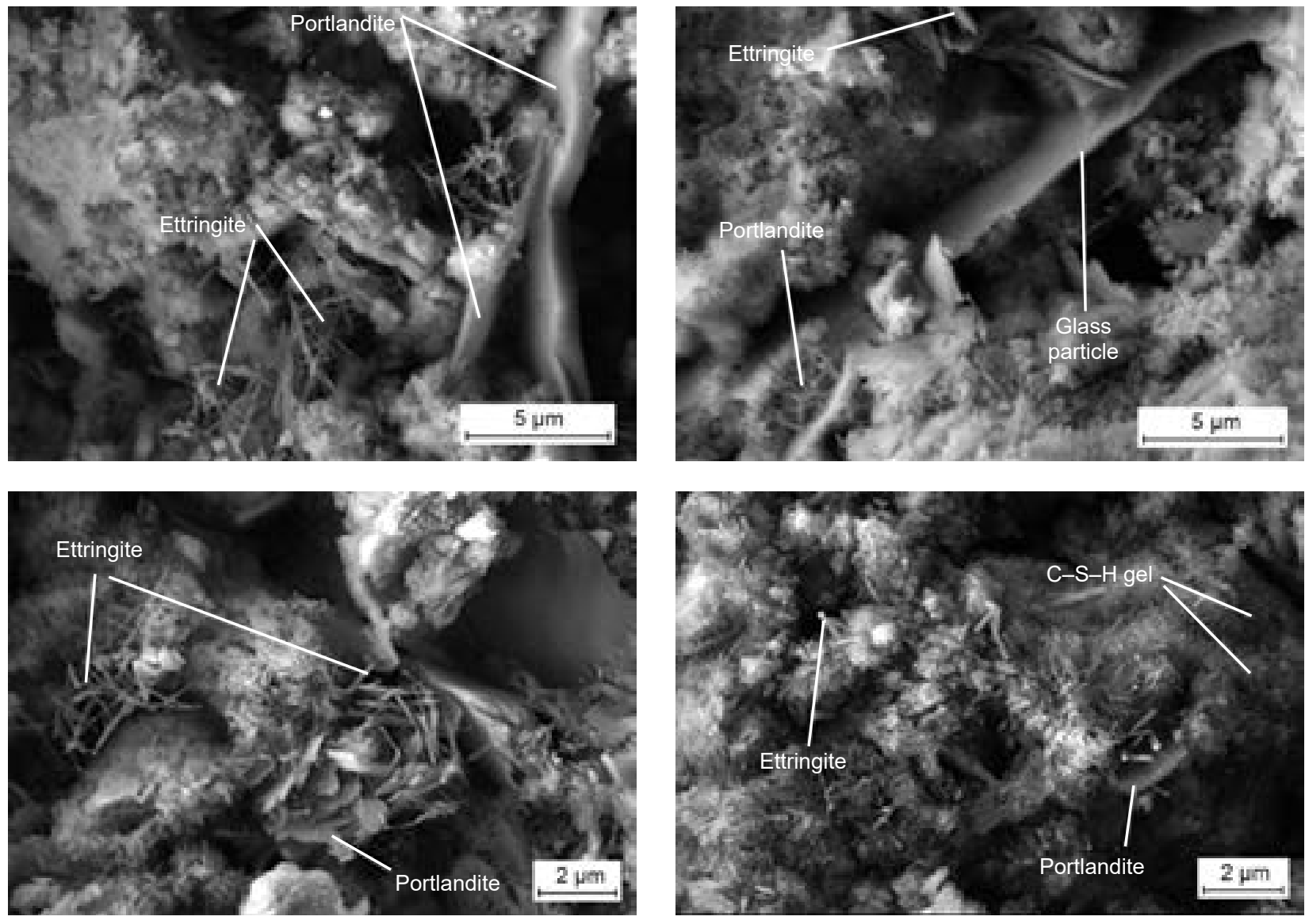

a)

b)

Figure 8. Microstructure of hardened cement paste: a) without ground waste glass; b) with $5 \%$ of ground waste glass. (Continue on next page) 

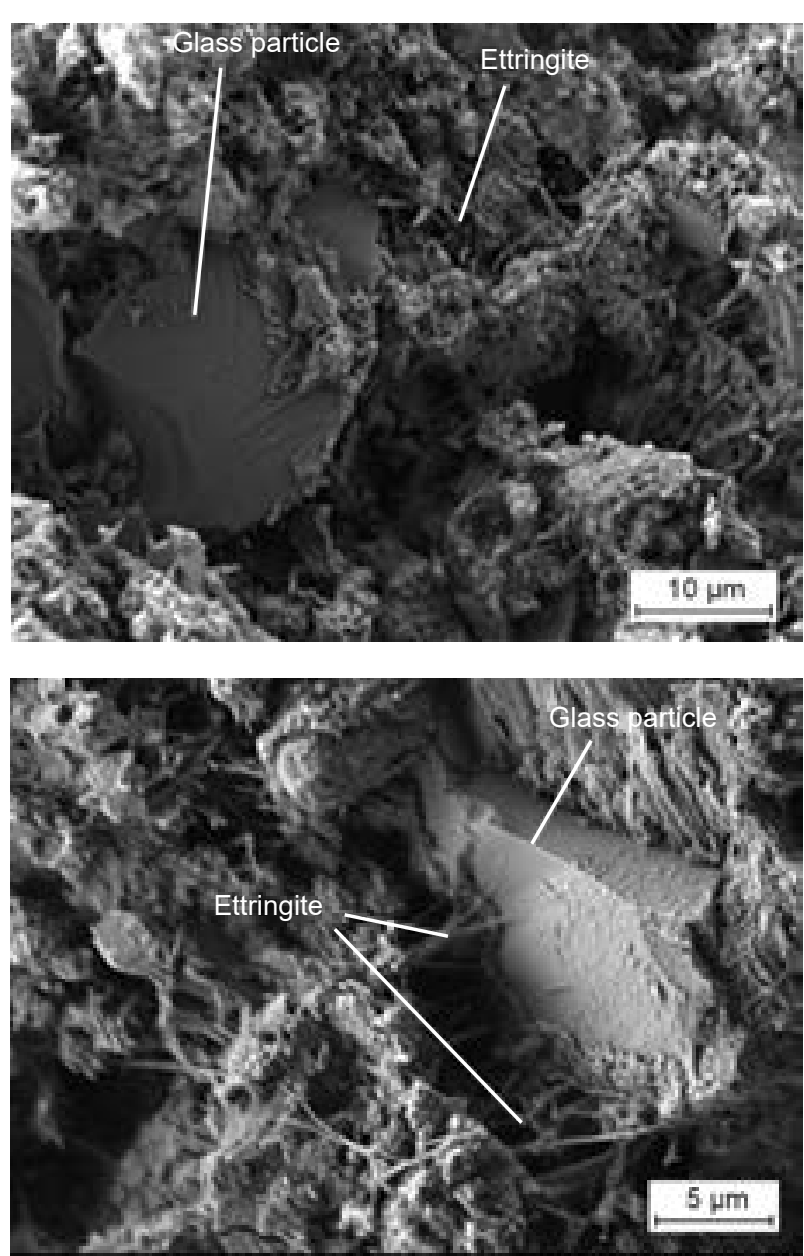

a)

Figure 8. Microstructure of hardened cement paste: c) with $30 \%$ of ground waste glass.

with ground waste glass; the remaining amount was made of quartz $(3.2 \%)$.

Microstructure tests on hardened cement paste specimens were made in addition to X-ray analyses. The microstructure was studied by means of an electron microscope, images of which are presented in Figure 8, showing the microstructure of specimens without ground waste glass and specimens where $5 \%$ and $30 \%$ of cement is replaced with ground waste glass. Figures $8 \mathrm{a}$ and $b$ present the hydration products of cement minerals, i.e., the hexagonal plates of portlandite $\left(\mathrm{Ca}(\mathrm{OH})_{2}\right)$ and needles of ettringite, which compose a dense structure of the cement matrix. The thickness of the ettringite crystals found in the cement matrix was approx. $10 \mu \mathrm{m}$ and the length of up to several hundred micrometres; however, these properties largely depend on the water and cement ratio, curing conditions, active mineral additives used and other factors.

An array of tests was conducted to analyse the effect of ground glass on the mechanical properties of cement mortars. The density decreases slightly with increasing amount of ground glass (see Figure 9) leading

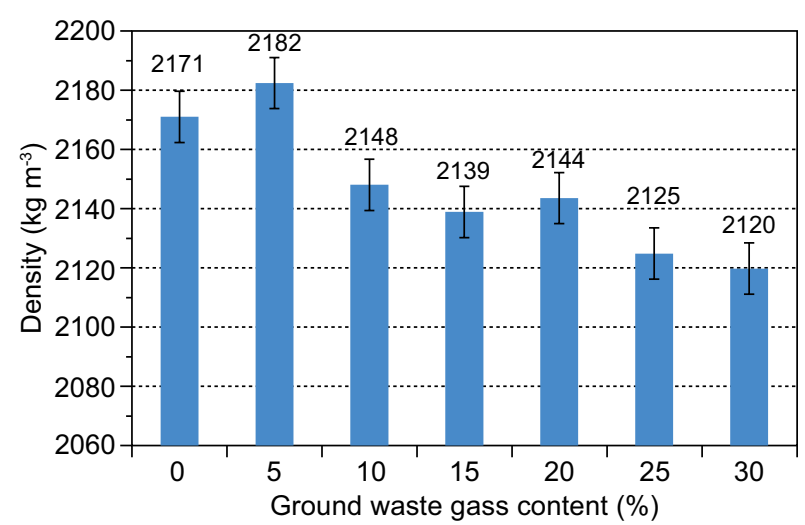

Figure 9. Relationship between the density and the amount of ground waste glass in cement mortar.

to the conclusion that in cement mortars it is effective to replace up to $30 \%$ of cement with ground glass.

The tests determined the effect of the amount of ground waste glass on the ultrasonic pulse velocity in cement mortar specimens (Figure 10). After 28 days of curing of hardened cement paste where $5 \%$ of cement was replaced with ground waste glass, the increase in the ultrasonic pulse velocity was observed with UPV value of $4156 \mathrm{~m} \cdot \mathrm{s}^{-1}$. Compared to the values of the control specimens, these results represent an increase of $1.27 \%$. Tests results of the ultrasonic pulse velocity contribute to and confirm the results of density measurement.

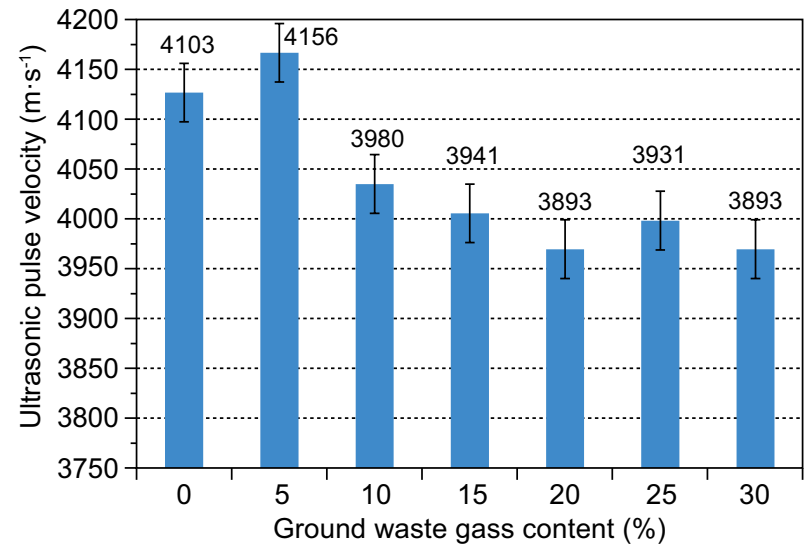

Figure 10. Relationship between the ultrasonic pulse velocity and the amount of ground waste glass in cement mortar.

Figure 11 presents the results of the compressive strength tests made with cement mortar. The highest compressive strength of $76.5 \mathrm{MPa}$ was received testing the cement mortar cured for 28 days, in which $5 \%$ of cement was replaced with ground waste glass. The increased amount of ground waste glass up to $30 \%$ resulted in the lowest compressive strength value of 56.7 MPa.

The analysis of density, ultrasonic pulse velocity and compressive strength test results of cement mortar leads to the conclusion that up to $5 \%$ of cement can be 


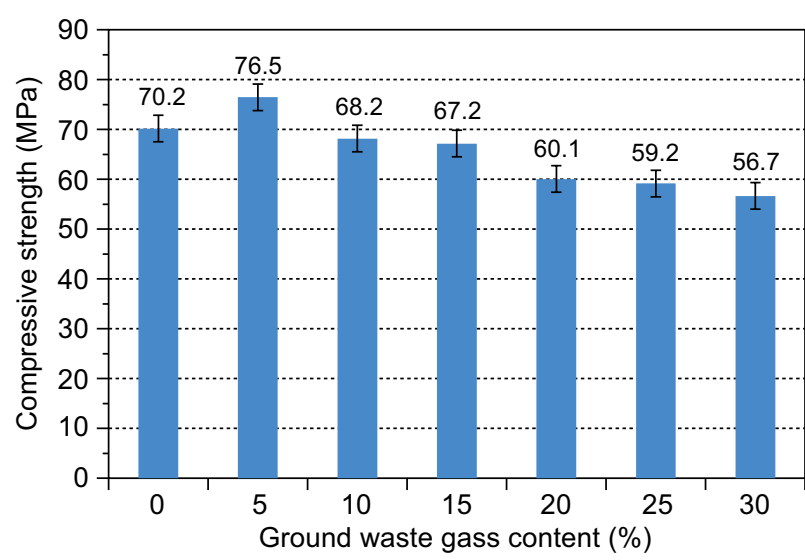

Figure 11. Relationship between the compressive strength and the amount of ground waste glass in cement mortar.

replaced with ground waste in cement mortar without compromising the strength properties of the mortar.

Figure 12 shows the relationship between the bending strength and the amount of ground waste glass in cement mortar specimens cured for 28 days.

In specimens cured for 28 days the values of the bending strength grew with the increase in the amount of ground waste glass up to $5 \%$. The bending strength of the control specimen without ground waste glass was 6.3 MPa. The replacement of $5 \%$ of cement with ground waste glass resulted in the highest bending strength of 7.1 $\mathrm{MPa}$, which was $0.8 \mathrm{MPa}$ higher compared to the control specimen.

The microstructure was studied by means of electron microscopy, images of which are presented in Figure 13, showing the microstructure of specimens without ground waste glass and with $5 \%$ of cement replaced with ground waste glass.

Based on the tests, ground waste glass can be used in mortars to replace $5 \%$ of cement as ground waste glass increases the density, the ultrasonic pulse velocity, as well as compressive and bending strengths of mortar. Such mixtures can be used for construction.

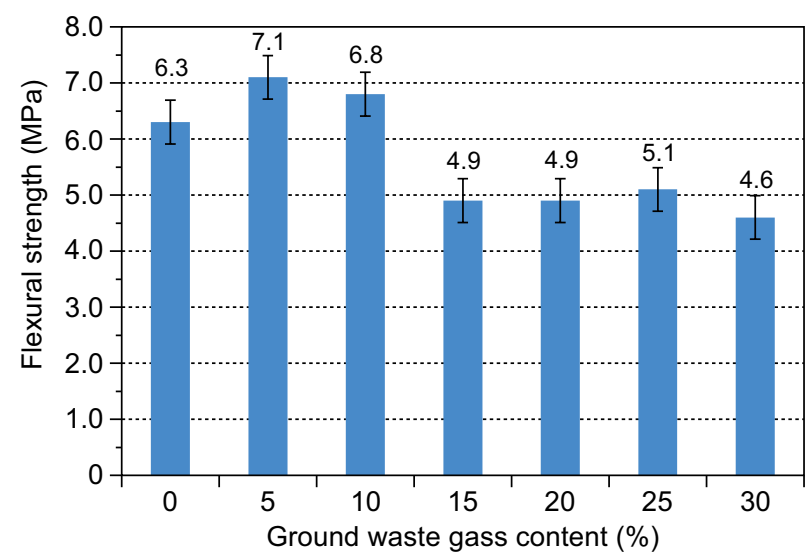

Figure 12. Relationship between the bending strength and the amount of ground waste glass in cement mortar.



a)

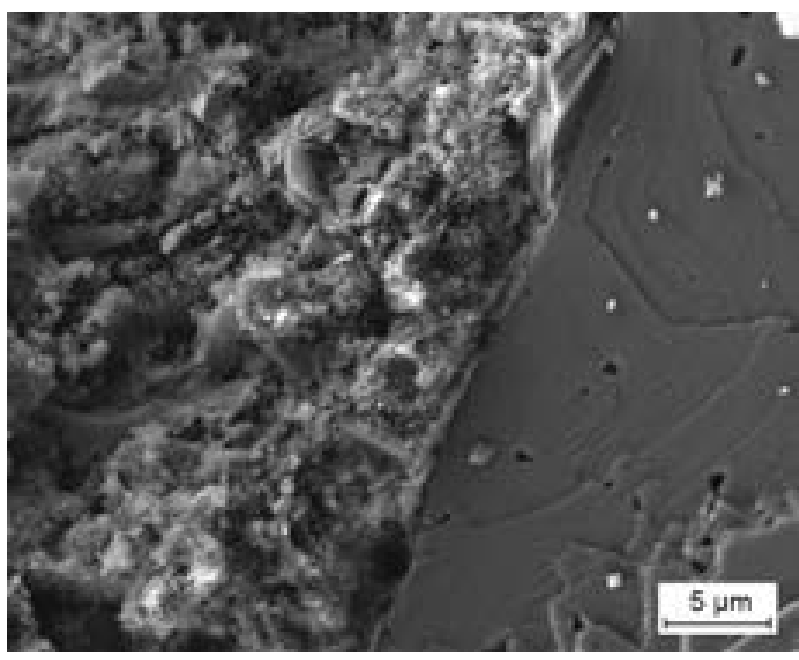

b)

Figure 13. Microstructure of cement mortar: a) without ground waste glass; b) with $5 \%$ of ground waste glass.

\section{CONCLUSIONS}

A scanning electron microscopy was used to find irregularly shaped particles of ground waste glass with an average size of approx. $15 \mu \mathrm{m}$. Particles of ground waste glass are composed of many irregular and angular crystals dispersed in different directions and ranging in size of up to $0.56 \mu \mathrm{m}$. Quartz was found to be the prevalent element in the waste glass with a total content of $68.15 \%$.

Tests with hardened cement paste revealed that the highest value of density was obtained after seven days of curing the hardened cement paste, in which $5 \%$ of cement was replaced with ground waste glass. This percentage of ground waste glass also resulted in the highest densities after 28 and 56 days of curing. The results of ultrasonic pulse velocity measurement in specimens cured for 7, 28 and 56 days suggested that the velocity was the fastest in specimens with $5 \%$ of 
cement replaced with ground waste glass and amounted to $3445 \mathrm{~m} \cdot \mathrm{s}^{-1}$ after 7 days, $3554 \mathrm{~m} \cdot \mathrm{s}^{-1}$ after 28 days and $3747 \mathrm{~m} \cdot \mathrm{s}^{-1}$ after 56 days.

The tests of densities, the ultrasonic pulse velocity as well as compressive and bending strengths of hardened cement paste and mortar demonstrated that these properties improved in hardened cement paste and mortars modified with $5 \%$ ground waste glass by weight of cement. This result can be explained by a dense structure without large pores and extremely strong adhesion of cement to the waste and results show that the ground glass is pozzolanically active. Such mixtures can be used for construction.

It was determined that the replacement of more than $5 \%$ of cement with ground waste glass in hardened cement paste and mortar reduced the values of densities, the ultrasonic pulse velocity as well as compressive and bending strengths. This result can be explained by the insufficient amount of cement and the excess quantities of free glass that did not engage in the production of secondary hydration products $\mathrm{C}-\mathrm{H}-\mathrm{S}$ minerals.

\section{REFERENCES}

1. Shekhawat B. S., Aggarwal V. (2014): Investigation of strength and durability parameters of glass powder-based concrete. International Journal of Engineering Research \& Technology (IJERT), 3(7), 333-338.

2. Meyer C., Egosi N., Andela C. (2001). Concrete with waste glass as aggregate. In: Dhir R. K., Limbachiya M. C., Dyer T. D. (Eds.) Recycling and re-use of glass cullet. Proceedings of the International Symposium Concrete Technology Unit of ASCE and University of Dundee, 19-20 March, 2001.

3. Nagrockienė D., Skripkiūnas G. (2015): Stiklo atliekų panaudojimas gaminant betoną. Structum, 4, 96-97.

4. Byars E. A., Morales B., Zhu H. Y. (2004). ConGlassCrete I (Project code GLA2-006). The Waste and Resources Action Programme, Oxon, UK.

5. Topcu I. B., Canbaz M. (2004): Properties of concrete containing waste glass. Cement and Concrete Research, 34(2), 267-274. doi: 10.1016/j.cemconres.2003.07.003

6. Manmohan D., Metha P. K. (1981): Influence of pozzolanic, slag and chemical admixtures on pore size distribution and permeability of hardened cement pastes. Cement Concrete and Aggregates, 3, 63-67. doi: 10.1520/CCA10203J

7. Sellevold E. J., Bager D. H., Klitgaard Jensen E., Knudsen T. (1982). Silica fume cement paste - hydration and pore structure. Norwegian Institute of Technology, University of Trondheim, Norway, pp. 19-50.

8. Marsh B. K., Day R. L., Bonner D. G. (1985): Pore structure characteristics affecting the permeability of cement paste containing fly ash. Cement and Concrete Research, 15, 1027-1038. doi: 10.1016/0008-8846(85)90094-8

9. Cur R. (1991). Fly ash as addition to concrete (Vol. 144). Center for Civil Engineering Research and Codes, Gouda, The Netherlands.

10. Tumidajski P. J. (2006): Effect of slag, silica fume, and finishing on the sorptivities of field concrete. Canadian
Journal of Civil Engineering, 33, 1022-1026. doi: 10.1139/ 106-048

11. Samtur H. R. (1974). Glass recycling and reuse (Report 17). University of Wisconsin, Madison Institute for Environmental Studies.

12. Shao Y., Lefort T., Moras S., Rodriguez D. (2000): Studies on concretes containing ground waste glass. Cement and Concrete Research, 30, 91-100. doi: 10.1016/S0008-8846 (99)00213-6

13. Meyer C., Baxter S., Jin W. (1996). Alkali-silica reaction in concrete with waste glass as aggregate. In: Materials for a New Millennium, Proceedings of ASCE Materials Engineering Conference, Washington DC. pp. 1388-1394.

14. Shi C., Wu Y., Riefler C., Wang H. (2005): Characteristics and pozzolanic reactivity of glass powder. Cement and Concrete Research, 35, 987-993. doi: 10.1016/j.cemconres. 2004.05.015

15. Idir R., Cyr M., Tagnit-Hamou A. (2011): Pozzolanic properties of fine and coarse color-mixed glass cullet. Cement and Concrete Composites, 33, 19-29. doi: 10.1016/j.cemconcomp.2010.09.013

16. Zidol A. (2009). Optimisation de la finesse de la poudre de verre dans les systèmes cimentaires binaires (Master Thesis). University of Sherbrooke, Canada.

17. Shayan A., Xu A. (2006): Performance of glass powder as a pozzolanic material a field trial on concrete slabs. Cement and Concrete Research, 36, 457-468. doi: 10.1016/j.cemconres.2005.12.012

18. Aladdine F. (2009). Propriétés mécaniques et durabilité des bétons incorporant du verre finement broyé (Master Thesis), University of Sherbrooke, Canada.

19. Kateb M. L. (2009). Utilisation des granulats de verre dans la fabrication des bétons architecturaux, cas de briques en bétons (Master Thesis). Sherbrooke, Canada.

20. Taha B., Nounu G. (2008): Properties of concrete contains mixed colour waste recycled glass as sand and cement replacement. Construction and Building Materials, 22, 713-720. doi: 10.1016/j.conbuildmat.2007.01.019

21. Idir R., Cyr M., Tagnit-Hamou A. (2010): Use of fine glass as ASR inhibitor in glass aggregate mortars. Construction and Building Materials, 24, 1309-1312. doi: 10.1016/j.conbuildmat.2009.12.030

22. Gunalaan V., Kanapathy P.S.G. (2013): Performance of Using waste glass powder in concrete as replacement of cement. American Journal of Engineering Research, $12,175-181$.

23. Vandhiyan R., Ramkumar K. and Ramya R. (2013): Experimental study on replacement of cement by glass powder. International Journal of Engineering Research and Technology, 2(5), 234-238.

24. Kumarappan N. (2013): Partial replacement cement in concrete using waste glass. International Journal of Engineering Research and Technology, 2, 2278-0181.

25. Vijayakumar G., Vishaliny H., Govindarajulu D. (2013): Studies on glass powder as partial replacement of cement in concrete production. International Journal of Emerging Technology and Advanced Engineering, 3(2), 153-157.

26. Nwaubani S.O., Poutos K. I. (2013): The influence of waste glass powder fineness on the properties of cement mortars. International Journal of Application or Innovation in Engineering and Management, 2(2), 110-116.

27. Khatib J.M., Sohl H.S., Sohl H.S., Chileshe N. (2012): Glass powder utilisation in concrete production. European 
Journal of Applied Sciences, 4(4), 173-176. doi: 10.5829/ idosi.ejas.2012.4.4.1102

28. Dhirendra P., Yadav R.K., Chandak R. (2012): Strength characteristics of pre-cast concrete blocks incorporating waste glass powder. Journal of Engineering Sciences, 1, $1-8$.

29. Jangid J. B., Saoji A.C. (2014): Experimental investigation of waste glass powder as the partial replacement of cement in concrete production. Journal of Mechanical and Civil Engineering, 4, 55-60.

30. Harish B., Hanumesh B., Siddesh T., Siddhalingesh B. (2016): An experimental investigation on partial replacement of cement by glass powder in concrete. International Research Journal of Engineering and Technology, 3(10), 1218-1224
31. Dali J.S., Tande S.N. (2012). Performance of Concrete Containing Mineral Admixtures Subjected to High Temperature. In: Proceedings of $37^{\text {th }}$ Conference on Our World in Concrete and Structures, Singapore.

32. Khmiri A., Samet B., Chaabouni M. (2012): Assessment of the Waste Glass Powder Pozzolanic Activity by Different Methods. International Journal of Research and Reviews in Applied Sciences 10, 322-328.

33. Mohan P. D., Keshav S. K. (2013): Experimental Investigation of Waste Glass Powder as Partial Replacement of Cement in Concrete. International Journal of Advanced Technology in Civil Engineering, 1, 112-118.

34. Anwar A. (2016): The influence of waste glass powder as a pozzolanic material in concrete. International Journal of Civil Engineering and Technology, 6, 131-148. 